\title{
Chlorite cement and its effect on the reservoir quality of sandstones from the Panyu low-uplift, Pearl River Mouth Basin
}

\author{
Chen Guojun ${ }^{1}$, Du Guichao ${ }^{1,3 *}$, Zhang Gongcheng ${ }^{2}$, Wang $\mathbf{Q i}^{1}$, Lv Chengfu ${ }^{1}$ \\ and Chen $\mathrm{Ji}^{1,3}$ \\ ${ }^{1}$ Key Laboratory of Petroleum Resources Research, Institute of Geology and Geophysics, Chinese Academy of Sciences, \\ Lanzhou 730000, China \\ ${ }^{2}$ CNOOC Research Center, Beijing 100027, China \\ ${ }^{3}$ Graduate University of the Chinese Academy of Sciences, Beijing 100049, China
}

(C) China University of Petroleum (Beijing) and Springer-Verlag Berlin Heidelberg 2011

\begin{abstract}
Based on porosity and permeability measurements, mercury porosimetry measurements, thin section analyses, SEM observations, X-ray diffraction (XRD) analysis and granulometric analyses, diagenetic features of reservoir sandstones taken from the Zhuhai formation in the Panyu low-uplift of the Pear River Mouth Basin were examined. This study shows that chlorite cements are one of the most important diagenetic features of reservoir sandstones. The precipitation of chlorite was controlled by multiple factors and its development occurred early in eo-diagenesis and continued till Stage A of middle diagenesis. The precipitation of chlorite at the early stage was mainly affected by the sedimentary environment and provenance. Abundant $\mathrm{Fe}$ - and $\mathrm{Mg}$-rich materials were supplied during the deposition of distributary channel sediments in the deltaic front setting and mainly in alkaline conditions. With the burial depth increasing, smectite and kaolinite tended to be transformed into chlorite. Smectite cements were completely transformed into chlorite in sandstones of the studied area. Volcanic lithics rich in Fe and $\mathrm{Mg}$ materials were dissolved and released $\mathrm{Fe}^{2+}$ and $\mathrm{Mg}^{2+}$ into the pore water. These cations precipitated as chlorite cements in middle diagenesis in an alkaline diagenetic environment. Chlorite coatings acted as porosity and permeability, thus helping preserve cements in the chlorite cemented sandstones. The reservoir quality of chlorite cemented sandstones is much better than sandstones without chlorite cements. Chlorite cements play an important role in the reservoir evolution that was mainly characterized by preserving intergranular porosity and forming better pore-throat structures of sandstones.
\end{abstract}

Key words: Chlorite cement, diagenesis, reservoir quality, Panyu low-uplift, Pearl River Mouth Basin

\section{Introduction}

Chlorite cements are often present in deltaic and shallow marine reservoir sandstones. They are significant authigenic constituents in diagenesis and play an effective role in the evolution of reservoir quality. The origin of chlorite cement is complex and its precipitation is controlled by the material source, pore water, early clay minerals and sealing or opening of the system (Huang et al, 2004). As indicated by studies of different areas, the diagenetic stage of chlorite differs in specific diagenetic conditions. It could develop from the stage of eo-diagenesis $\left(\sim 20^{\circ} \mathrm{C}\right)$ to meso-diagenesis and displaces detrital grains (Grigsby, 2001). Tian (2008) identified that its precipitation began at stage A of eo-diagenesis (before effective compaction) and continued till stage $\mathrm{C}$ of meso-

*Corresponding author. email: duguichao@sina.com Received November 8, 2010 diagenesis. Sun (2008) pointed out that its precipitation occurred at the early and middle diagenetic stages and that chlorite formed at the early stage could continue to grow throughout the diagenetic history. Liu (2009) and Li (2006) showed that chlorite cements developed only at stage A of eo-diagenesis. As documented in these studies, burial depths with the occurrence of chlorite differ from place to place: lower than $1 \mathrm{~km}$ to $2-2.5 \mathrm{~km}$ (Billault et al, 2003); $2-4.5 \mathrm{~km}$ (Lynch, 1997); 1.8 km (Grigsby, 2001); 1770-2000 m (Peng et al, 2009); 5850-6120m (Wang et al, 2007). Its diagenetic temperature is between $20-40{ }^{\circ} \mathrm{C}$ and $70-80{ }^{\circ} \mathrm{C}$ (Billault et al, 2003). The relationship between chlorite cements and better reservoir quality has been identified decades ago. Previous studies show that chlorite coatings are major causes of anomalous porosity and permeability (Sun et al, 2008), especially in deeper reservoir sandstones (Anjos et al, 2003; Bloch et al, 2002; Thomson, 1979).

This study was based on an analysis of twenty-five 
reservoir sandstones from the Zhuhai formation in the Panyu low-uplift, aiming at determining the major diagenetic features, the occurrence and morphology of chlorite, the timing and diagenetic stage of chlorite growth, and the origin of chlorite. One of the most important goals of this study is to analyze the effect of chlorite on reservoir quality and determine the mechanisms under which high porosity and permeability were formed.

\section{Geological setting}

The Panyu low-uplift, situated in the south of the Pearl River Mouth Basin, is bounded on the east by the Dongsha uplift and the west by the Shenhu Ansha uplift. It dipped southward and disappeared in the Baiyun sag and is basically seen as a low uplift that developed on the upper Tertiary background (Xie et al, 2009). It is the main area where deltaic and offshore sediments developed and evolved during the late Cenozoic, with the depth of water at 100 to $400 \mathrm{~m}$ (averaging $200 \mathrm{~m})$. The Panyu low-uplift is one of the most important oil production areas and most petroliferous areas in the Pear River Mouth basin. Quite a number of large and mediumsized gas fields have been discovered here since 2001, with a proven gas reserve of nearly $800 \times 10^{8} \mathrm{~m}^{3}$ (Zhang et al, 2010).

Affected by tectonic movements, the geological evolution of the basin can be divided into three main tectonic stages: 1) the rifting stage from the late Cretaceous period till the early Oligocene; 2) the depression stage from the late Oligocene to the early Miocene; and 3) the block faulting stage from the late Miocene to the present (Zhang et al, 2004). Eight formations from the bottom to the top have been recognized, including the Eocene Wenchang Formation, the Oligocene Enping and Zhuhai formations, the Miocene Zhujiang Formation, the Hanjiang Formation and the Yuehai Formation, the Pliocene Wanshan Formation and the Quaternary. Thick and extensively distributed middle-deep lacustrine mudstone in the Eocene-Oligocene Enping and Wencang formations in the adjacent Baiyun sag has been identified as the main source rock (Guo et al, 2009). The principal oil and gas bearing reservoirs are distributed in the Yuehai, Hanjiang and Zhujiang formations (Yu et al, 2007).

\section{Mineralogy and petrography}

The sandstones at a sampled depth of 2765.5-2783.06m in the upper Zhuhai formation are mostly from fine to medium grained sublitharenite in the sandstone classification of McBride (1963) (Fig. 1). The average framework composition of the sandstones is $\mathrm{Q}_{84} \mathrm{~F}_{3} \mathrm{~L}_{13}$. Lithic grains include volcanic rock fragments $(5-15 \%)$ and metamorphic rock fragments $(<5 \%)$, particularly quartz schist, phyllite and metamorphic quartz debris. Sericitezation occurred in volcanic debris. Sandstones at a sampled depth of $3221.7-3244.78 \mathrm{~m}$ in the lower part of the Zhuhai formation are not as compositional and texturally mature as those from the upper part. They are categorized as poorly to moderately sorted and as fine to medium grained sublitharenite. The content of detrital quartz grains is less than $85 \%$, lithic grains less than $25 \%$ and feldspar grains less than $4 \%$. The average framework composition of the sand- stones is $\mathrm{Q}_{80} \mathrm{~F}_{3} \mathrm{~L}_{17}$. Lithic grains are abundant and dominated by volcanic rock fragments (10-25\%) and metamorphic rock fragments $(<5 \%)$. The petrographic work confirms that $75 \%$ of the detrital quartz grains originated from granite rocks, only $15 \%$ of them from metamorphic rocks. Feldspar grains are particularly plagioclase and microcline with the total volume lower than $5 \%$.

Diagenetic components include cements of quartz $(3 \%)$, authigenic kaolinite, chlorite $(0.5-2 \%)$, illite, smectite, calcite, Fe-dolomite and siderite. Ten samples that developed with chlorite cements were selected to characterize the grain-size distribution as shown in Fig. 2.

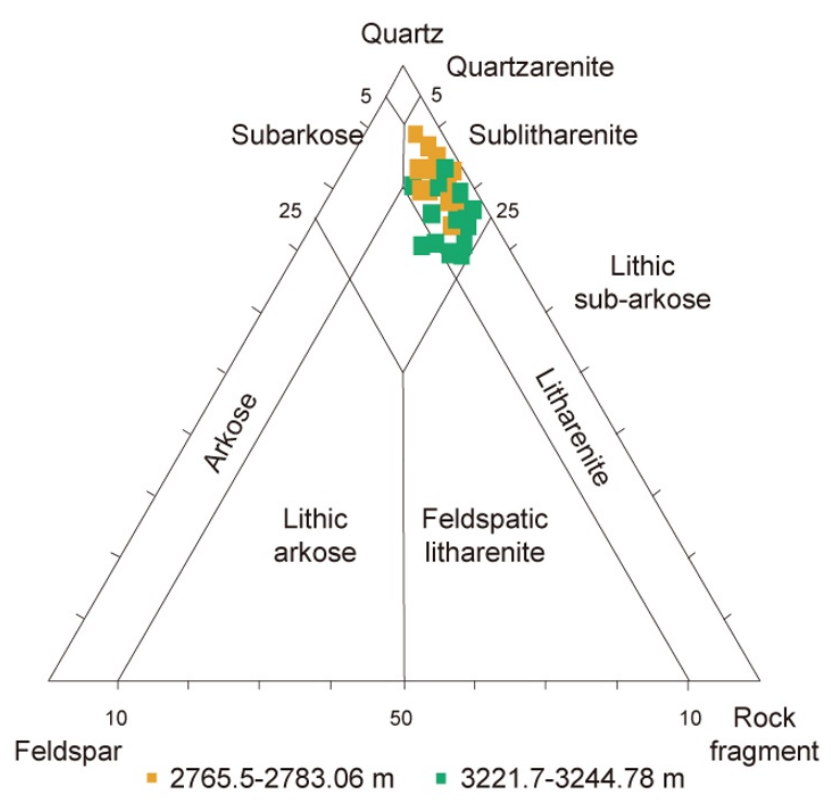

Fig. 1 Classification of the sandstones under McBride's 1963 classification scheme

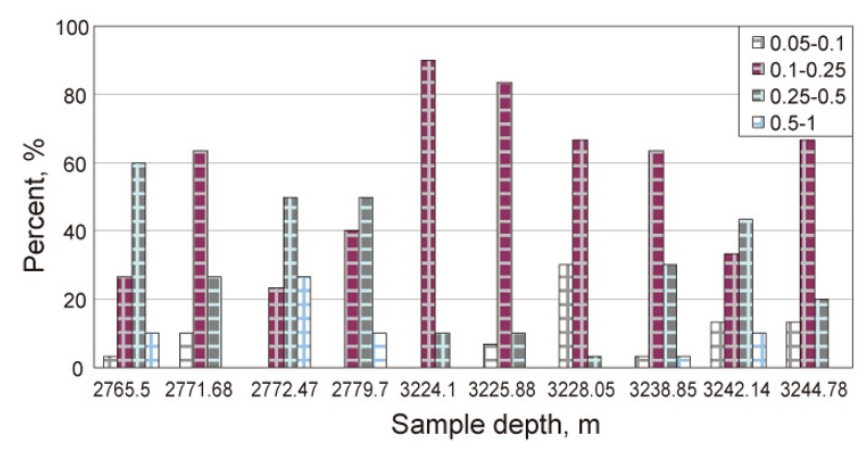

Fig. 2 Grain size distribution of sandstones with chlorite cements

\section{Diagenetic alterations}

Diagenetic features observed in the sandstones include compaction, carbonate cementation, feldspar and lithic grains dissolution, quartz overgrowth and authigenic clay mineralization. Sandstones were moderately to strongly 
compacted with mainly point-line grain contacts and line contacts. During their compaction, ductile grains were weakly or strongly deformed. Concave-convex contacts, formed by pressure dissolution, were occasionally observed in samples taken at a depth of less than $3225.88 \mathrm{~m}$. Dissolution in the studied sandstones is mainly characterized by dissolution of volcanic lithics and feldspar grains (Fig. 3-a,b). It is the main factor that generated secondary porosity (averaging $5 \%$ of porosity).

The cements are quartz, carbonate (siderite, calcite and ankerite) and clays (kaolinite, illite, chlorite). Authigenic quartz commonly occurs as quartz overgrowth and small crystals filling intergranular pores and secondary pores. Although quartz cement is widely developed in nearly all the studied samples, it is not volumetrically significant in these sandstones, with an average volume of lower than $3 \%$, so it does not cause much damage to the porosity.

Carbonate cements and chlorites are the most characteristic cement types in sandstones of the studied area. Calcite commonly occurs as concretions and is heterogeneously distributed. Calcite occurs as basal cements with a content of trace to $30 \%$ (highest in samples from a depth of $2771.68 \mathrm{~m}$ and $2779.7 \mathrm{~m}$ ) and the sandstones are fine-medium grained, poorly sorted with a pre-calcite cemented porosity of up to
40 or $45 \%$, which shows a characteristic of pre-compaction cementation. This calcite predates all the other diagenetic alterations. Ankerite filled intergranular pores and secondary pores and displaced detrital grains and quartz overgrowth, indicating that this ankerite developed later than the quartz overgrowths and dissolution of volcanic rock fragments and feldspars. Fine grained siderite occurred as small scattered crystals, concretions in sandstones. It is always embedded in ankerite concretions, showing that it developed prior to the ankerite. Siderite also predated dissolution as indicated by filling of the cements in secondary pores in volcanic rock fragments (VRF) and feldspars.

Secondary porosity was formed because of the dissolution of VRF and feldspar. Oversize pores were occasionally observed and caused by complete dissolution of unstable grains. The content of secondary porosity does not show an increasing trend and varies between trace and 7\% (averaging $5 \%$ ). Such dissolution was inhibited by chlorite coatings, as VRF and feldspar were dissolved and the chlorite coated grains remained in chlorite cemented samples. Quartz overgrowth was typically inhibited by chlorite cements. Quartz secondary overgrowth seldom occurred in chlorite cemented sandstones and developed only when chlorite coating is thin or discontinuous (Fig. 3-a,c; Fig. 4-c).
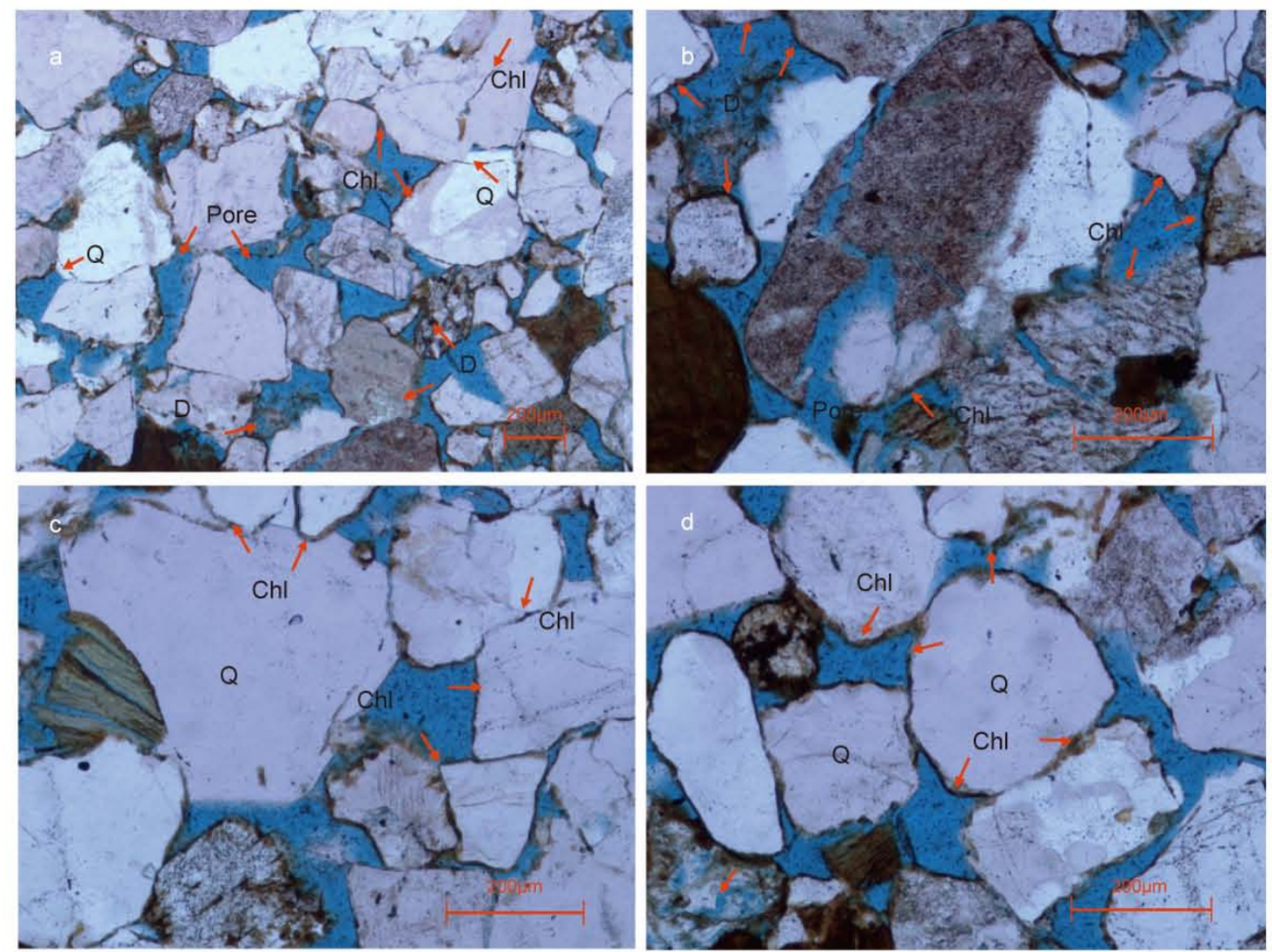

Fig. 3 Sample from a depth of $3242.14 \mathrm{~m}, \mathrm{E}_{3}{ }^{2} \mathrm{zh}$. a) intergranular pores preserved by chlorite coatings; minor dissolution of VRF and feldspar grains protected by coatings; minor quartz overgrowth; b) dissolution of VRF and chlorite coatings; some of these grains were completely dissolved forming oversized pores. Dissolution provides materials for adjacent precipitation of chlorite coatings; c) chlorite coatings developed at the contact of quartz grains and covered the detrital grains; d) Intergranular porosity is well preserved and no quartz overgrowth developed. (Q: Quartz; Chl: Chlorite; P: Pore; QO: Quartz Overgrowth; D: Dissolution) 


\section{Chlorite}

\subsection{Occurrence and morphology}

The cementation of chlorite, most of which is Fe-chlorite, is the most important diagenetic feature in authigenic cements of the studied sandstones. Generally, chlorites are the most common authigenic clay minerals in sediments and they supply information about the diagenetic history and the chemical composition of pore waters (Berger et al, 2009). During their diagenesis, chlorites form preferentially in an alkaline environment with a high $\mathrm{pH}$ value and a high content of $\mathrm{Fe}$ ion. Chlorite is present in three different types: 1) chlorite coatings (Fig. 4-a). Chlorite crystals are oriented perpendicular to grain surfaces. Coatings commonly are $5-10 \mu \mathrm{m}$ and partly or wholly cover detrital grains (Fig. 4-b). Chlorite grain coatings are present both on the grain surface and along the grain contact surface (Fig. 3-a); 2) pore fillings. This chlorite is comprised by chlorite plates that are oriented parallel to the grain surfaces and grew toward the center of pores. 3) scattered and isolated chlorite crystals are common but volumetrically limited (Fig. 4-d). They occurred as chlorite plates that co-existed with small quartz crystals, kaolinite and illite.
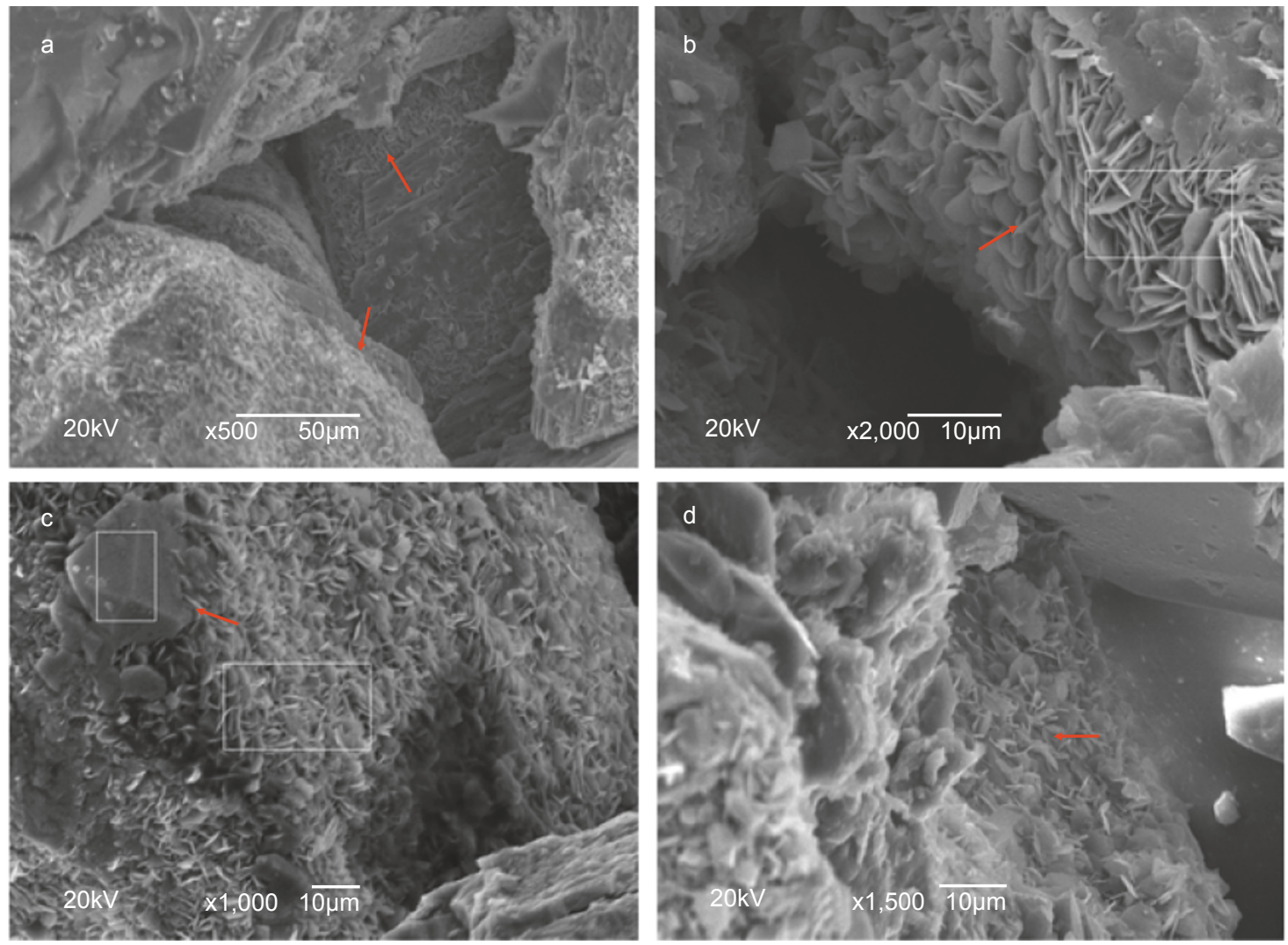

Fig. 4 a) PY27-1-1-22C, $3239.62 \mathrm{~m}, \mathrm{E}_{3}{ }^{2} \mathrm{zh}$. Detrital grains were coated by chlorite coatings and intergranular pores were preserved; chlorites grow on the surface of dissolved feldspar; b) PY27-1-1-25C, $3244.78 \mathrm{~m}, \mathrm{E}_{3}{ }^{2} \mathrm{zh}$. Chlorite rims covered the feldspar grains; c) PY27-1-1-23C, $3241.32 \mathrm{~m}, \mathrm{E}_{3}^{2} \mathrm{zh}$. Minor quartz grows where chlorite coatings are thin or discontinuous; d) PY27-1-1-11C, $3224.1 \mathrm{~m}, \mathrm{E}_{3}^{2} \mathrm{zh}$. Isolated chlorite crystals on surfaces of grains.

\subsection{Diagenetic stage of chlorite}

All the observed diagenetic features are illustrated in Fig. 5. Petrographic relationships are determined, based on analysis of thin sections and aided by scanning electron microscopy (SEM) to interpret the diagenetic stage of chlorites. This study shows that the formation of chlorites began early in eo-diagenesis and continued till stage A of middle diagenesis. 1) Chlorite rims are particularly present along the contacts between grain surfaces, including point contacts and line contacts. This suggests that the coatings precipitated before sand grains were effectively compacted early in the burial history. Grain coatings were deformed when compaction increased after formation at the early stage.
2) In well developed chlorite cemented samples, little or no quartz overgrowth developed and only small quartz crystals are present on grain surfaces when chlorite coatings are thin or discontinuous, indicating that quartz overgrowth occurred after the development of this chlorite. 3) No smectite was detected in sandstones and the alteration of smectite could be a potential source for chlorites. A possible explanation is that smectite was transformed to chlorite during burial diagenesis. 4) Chlorite plates co-existed with small quartz crystals and grew on the rigid surfaces of feldspar grains, suggesting that the dissolution of feldspar provided materials for chlorite precipitation and such chlorite postdated the dissolution of feldspar grains. 5) In chlorite cemented samples, VRF and feldspar not cemented by chlorites were partially or 
cements. So, a conclusion can be drawn that kaolinites have not been transformed to chlorite yet in the studied sandstones.

Provenance-controlled chlorites in middle diagenesis were derived from the alterations of VRF, feldspar and minor shallow metamorphic lithic rock fragments. High percentage of volcanic clasts was added in sediments from source area in this depositional stage and alteration of volcanic materials caused high Fe concentrations. These Fe ions react with mud in rocks to form chlorites through the process:

$$
\begin{aligned}
& 4 \mathrm{Fe}^{2+}+2 \mathrm{Mg}^{2+}+3 \mathrm{Al}_{2} \mathrm{Si}_{2} \mathrm{O}_{5}(\mathrm{OH})_{4}+9 \mathrm{H}_{2} \mathrm{O}= \\
& \mathrm{Fe}_{4} \mathrm{Mg}_{4} \mathrm{Al}_{6} \mathrm{Si}_{6} \mathrm{O}_{20}(\mathrm{OH})_{16}+14 \mathrm{H}^{+}
\end{aligned}
$$

The diagenetic temperature for this chlorite precipitation is 90 to $120{ }^{\circ} \mathrm{C}$ (Zhu et al, 2008). Also, the dissolution of feldspars contributed partly to the formation of chlorites, although its content is limited. Evidence is showed that chlorites grew directly on the surfaces of dissolved feldspars. Alterations of volcanic materials have effects on chlorite formation are characterized in two aspects: 1) A sufficient content of VRF must be needed to provide an adequate source of ions. 2) Ductile lithics in VRF could be easily deformed as compaction increased when the content of VRF was high enough. This ductile deformation has a negative role in the formation of chlorites. Pittman (1992) showed that the optimum mafic VRF content is approximately $10 \%$ in sandstones containing more than $65 \%$ detrital quartz. Berger (2009) showed that Sanwan sandstones contained 12\% VRF and were favorable for chlorite precipitation. The content of VRF in the studied reservoir sandstones ranges from $5-15 \%$ (averaging 12\%) and their dissolution released abundant Fe, $\mathrm{Mg}$, Si and $\mathrm{Al}$ ions into pore water. These materials further form chlorite coatings or pore fillings.
Isolated and scattered chlorite crystals are volumetrically limited and generally precipitated later in middle diagenesis. At this stage, the evolution of organic matter reached a highly-mature stage. A significant volume of hydrocarbons filling the sandstone reservoir, together with the consumption of organic acids, results in the transformation of an acidic environment to an alkaline environment because of the strongly reducing nature of hydrocarbons (Wang, 1999). It is easy for the $\mathrm{Fe}, \mathrm{Mg}, \mathrm{Si}$ and $\mathrm{Al}$ ions in the pore water to react with other minerals to form chlorites.

\section{Reservoir quality}

\subsection{Pore types and pore-throat characteristics}

In chlorite cemented sandstones, intergranular pores are the main pore type (Fig. 3-a, d), including residual primary intergranular pores and dissolved intergranular pores. Such pores are heterogeneously distributed but showed good connectivity (Fig. 3-c, d). Their diameter commonly ranges from 10 and $200 \mu \mathrm{m}$. Interagranular dissolved pores seldom occur and are of a small size and have poor connectivity. Secondary pores were caused by the dissolution of VRF and feldspar protected by chlorite coatings. Its content is typically lower than $3 \%$, with its pore diameter smaller than $100 \mu \mathrm{m}$.

Chlorite cemented sandstones show a better pore size and pore-throat characteristics and a higher porosity and permeability. Their porosity is higher than $18 \%$ and maximum pore-throat diameter ranges from 6.7 to $21.3 \mu \mathrm{m}$ (averaging $14.3 \mu \mathrm{m}$ ). The porosity has better connectivity. By contrast, uncemented sandstones are characteristic of a smaller pore-throat diameter $(\max <2 \mu \mathrm{m}$, average $<1 \mu \mathrm{m})$ and a low porosity and permeability (Table 1 ).

\begin{tabular}{|c|c|c|c|c|c|}
\hline Samples & No. & $\begin{array}{l}\text { Mean pore-throat } \\
\text { diameter, } \mu \mathrm{m}\end{array}$ & $\begin{array}{l}\text { Max. pore-throat } \\
\text { diameter, } \mu \mathrm{m}\end{array}$ & $\begin{array}{c}\text { Porosity } \\
\%\end{array}$ & $\begin{array}{c}\text { Permeability } \\
\mu \mathrm{m}^{2} \times 10^{-3}\end{array}$ \\
\hline \multirow{4}{*}{$\begin{array}{c}\text { Chlorite } \\
\text { cemented } \\
\text { sandstones }\end{array}$} & $11 \mathrm{C} / 3224.1$ & 2.442 & 6.661 & 18.1 & 1.2 \\
\hline & $14 \mathrm{C} / 3225.88$ & 3.219 & 9.689 & 19.2 & 87.4 \\
\hline & $21 \mathrm{C} / 3238.85$ & 6.339 & 19.736 & 18.4 & 198.4 \\
\hline & $24 \mathrm{C} / 3242.14$ & 5.641 & 21.315 & 21 & 274.5 \\
\hline \multirow{5}{*}{$\begin{array}{c}\text { Sandstones } \\
\text { without } \\
\text { chlorite } \\
\text { cement }\end{array}$} & $01 \mathrm{C} / 2765.5$ & 4.219 & 19.031 & 21.7 & 256.9 \\
\hline & $03 \mathrm{C} / 2771.68$ & 0.211 & 0.627 & 7.9 & 0.29 \\
\hline & $07 \mathrm{C} / 2779.7$ & 0.281 & 1.44 & 9.6 & 0.62 \\
\hline & $15 \mathrm{C} / 3228.05$ & 0.272 & 1.523 & 16.2 & 2.2 \\
\hline & $17 \mathrm{C} / 3232.46$ & 0.173 & 1.366 & 16 & 47.3 \\
\hline
\end{tabular}

Table 1 Petrophysical measurements of porosity, permeability and pore-throat diameter

\subsection{Porosity and permeability}

Reservoir quality measurements show that the porosity of twenty sampled sandstones ranges from 7.9 to $21.7 \%$, the permeability ranging from 0.29 to $605 \times 10^{-3} \mu^{2}$ (averaging
$107.9 \times 10^{-3} \mu^{2}$ ). Samples with well-developed chlorites have a porosity of 12.1 to $21 \%$ (averaging $17 \%$ ) and a permeability of 8.8 to $198.4 \times 10^{-3} \mu \mathrm{m}^{2}$ (averaging $130 \times 10^{-3} \mu \mathrm{m}^{2}$ ), while the porosity in samples without chlorite cements ranges from 7.9 
to $21.7 \%$ (averaging $15 \%$ ), the permeability ranging from 0.29 to $605 \times 10^{-3} \mu \mathrm{m}^{2}$ (averaging $86 \times 10^{-3} \mu \mathrm{m}^{2}$ ). Generally, reservoir sandstones (of the same grain size) with well-developed chlo-

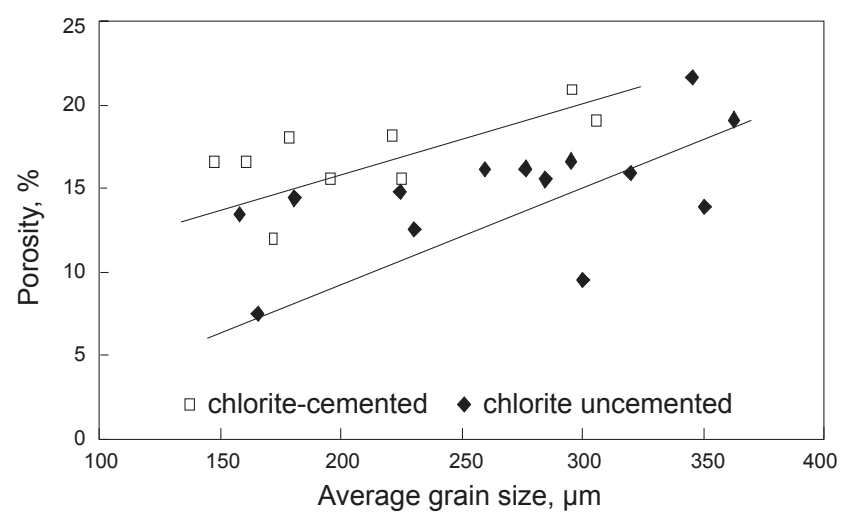

rites present a porosity of $6 \%$ higher and a permeability of 21 to $187 \times 10^{-3} \mu \mathrm{m}^{2}$ higher than those without chlorite cements (Fig. 6).

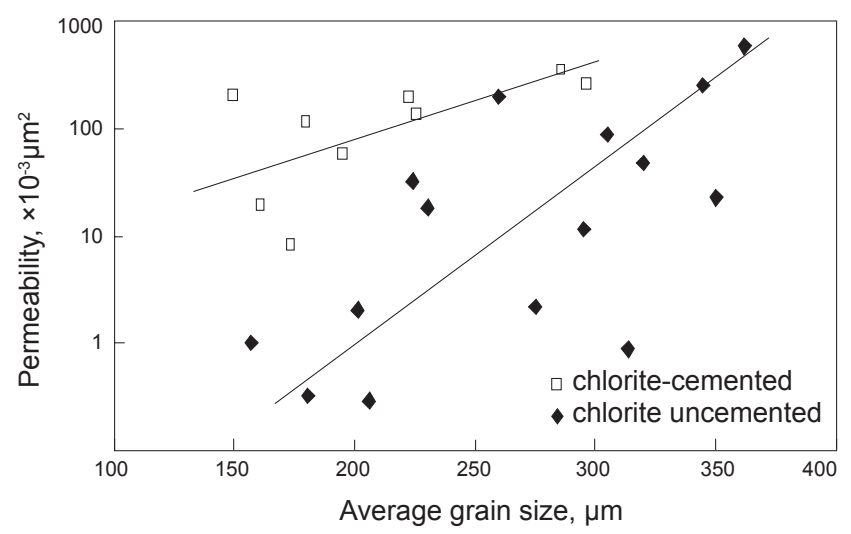

Fig. 6 Average grain size vs porosity and permeability in reservoir sandstones

\subsection{Effect of chlorites on reservoir quality}

Sampled sandstones are buried lower than $3300 \mathrm{~m}$ and show characteristics of moderate or moderate-to-strong compaction. In chlorite cemented sandstones, coatings particularly occurred covering detrital grains before effective compaction and were deformed when compaction increased (Fig. 3-a). Although there is no direct evidence used to confirm the relationship between anti-compaction and chlorite coatings, the inhibition of pressure dissolution by chlorite coatings is evident with the increase of compaction and they stopped the further densification of sandstones (Wang, 2007).

The development of quartz overgrowths is closely related to chlorite coatings. As represented in samples from a depth of $3242.1 \mathrm{~m}$, well-developed chlorites occurred as coatings covering detrital grains with contents of $2 \%$. Quartz overgrowths were effectively inhibited (Fig. 3-d). SEM observation shows that quartz cementation only occurred where chlorite coating is thin or discontinuous (Fig. 3-a). It was most common because their coatings covered the detrital grains and inhibited the contact between quartz grains and pore water. In sandstones without chlorite cements, quartz overgrowths tend to occur widely with a much higher content.

Secondary porosity was formed because of the dissolution of VRF and feldspars. In chlorite cemented sandstones, dissolution is effectively inhibited by chlorite coatings. The total intergranular and intragranular dissolved porosity ranges from 3 to $8 \%$ (averaging 5\%). As observed in thin sections and through SEM analysis, little dissolution occurred when detrital grains were coated by chlorite (Fig. 3-a), because chlorite coatings acted as effective barriers to the dissolution of VRF and feldspar grains, while detrital grains without coatings were partly or completely dissolved and generated abundant secondary porosity.

\section{Conclusions}

Three types of chlorite cements are present in the studied reservoir sandstones: chlorite coatings, pore-fillings and isolated chlorite crystals. Chlorite coating is one of the most important diagenetic features of the deltaic sandstones. The development of chlorite cements occurs early in eo-diagenesis and continues till Stage A of middle diagenesis.

Chlorite cemented sandstones typically have a higher porosity and permeability. Chlorite coatings that have an important effect on the evolution of reservoir quality are characterized by inhibiting pressure dissolution and quartz overgrowth, thus forming better pore-throat structures. The development of chlorite rims is favorable for preserving intergranular porosity and for the formation of better pathways for pore fluids, which promotes later dissolution of lithic grains.

For the origin of chlorite cements in distributary channel reservoir sandstones, the inflow of rivers supplied abundant materials for the precipitation of early chlorite coatings in a deltaic front environment. With the increase of the burial depth and the diagenetic temperature, smectites were transformed to chlorites, especially those that have been completely transformed to chlorites in meso-diagenesis. The most important source for chlorite cementation is the alteration of VRF, feldspar and minor metamorphic lithics. Dissolution of these ferromagnesian minerals provided abundant materials for chlorite cementation. On the other hand, chlorite coatings formed by these materials further covered the detrital grains and inhibited their dissolution. In reservoir sandstones mentioned in this study, the content of VRF ranges from 5 to $15 \%$ (averaging 12\%) and provides favorable conditions for chlorite cementation.

\section{Acknowledgements}

This study was financially supported by the China National Science \& Technology Project (2008ZX05025-006) and the China 973 Key Foundation Research Development Project (2009CB219400). Thanks are also given to the following individuals and institutions: Hao Lewei and Zhang Rui from the Key Laboratory of Petroleum Resources Research, the Institute of Geology and Geophysics, the Chinese Academy of Sciences; CNOOC Research Center 
provided all the related samples.

\section{References}

Anjos S M C, De Ros L F, and Silva C M A. Chlorite authigenesis and porosity preservation in the Upper Cretaceous marine sandstones of the Santos Basin, offshore eastern Brazil: International Association of Sedimentology Special Publication. 2003. 34: 291-316

Berger A, Gier S, and Krois P. Porosity-preserving chlorite cements in shallow-marine volcaniclastic sandstones: Evidence from Cretaceous sandstones of the Sawan gas field, Pakistan. AAPG Bulletin. 2009. 93(5): 595-615

Billault V, Beaufort D, Baronnet A, et al. A nanopetrographic and textural study of grain-coating chlorites in sandstone reservoirs. Clay Minerals. 2003. 38(3): 315-328

Bloch S, Lander R H, and Bonnell L. Anomalously high porosity and permeability in deeply buried sandstone reservoirs: Origin and predictability: AAPG Bulletin. 2002. 86(2): 301-328

Boles J R and Franks S G. Clay diagenesis in Wilcox sandstones of Southwest Texas: implications of smectite diagenesis on sandstone cementation. Journ. Sed. Petr. 1979, 49: 55-70

Chang H K, Mackenzie F T, and Schoonmaker J. Comparison between the diagenesis of dioctahedral and trioctahedral smectite, Brazilian offshore basins: Clay Minerals. 1986. 34 (4): 407-423

Grigsby J D. Origin and growth mechanism of authigenic chlorite in sandstones of the lower Vicksburg Formation, South Texas. J. Sedim. Res. 2001. 71: 27-36

Guo X W, He S, Shi H S, Zhu J Z. Hot fluid activities and the hydrocarbon accumulation in the PY30-1 structure of the Panyu Low Uplift, Pearl River Mouth Basin. Petroleum Exploration and Development. 2010. 37(3): 297-303

Huang S J, Xie L W, Zhang M, et al. Formation mechanism of authigenic chlorite and relation to preservation of porosity in nonmarine Triassic reservoir sandstones, Ordos Basin and Sichuan Basin, China. Journal of Chengdu University of Technology (Science \&Technology Edition). 2004. 31(3): 273-280 (in Chinese)

Klass R G, Kersey D G, Berg R R and Tieth T T. Diagenesis and secondary porosity in Vicksburg sandstones, McAllen Ranch Field, Hidalgo County, Texas: Gulf Coast Association of Geological Societies, Transactions. 1981. 31: 115-123

Li H, Liu Y Q, Liu L Y, et al. Diagenesis of Chang 8 reservoir with low permeability in the Xifeng oilfield, Ordos basin. Oil \& Gas Geology. 2006. 27(2): 209-217 (in Chinese)

Liu J K, Peng J, Liu J J, Wang Y, et al. Pore-preserving mechanism of chlorite rims in tight sandstone - an example from the T3x Formation of the Baojie area in the transitional zone from the center to the south of the Sichuan Basin. Oil \& Gas Geology. 2009. 30(1): 53-58 (in Chinese)

Lynch F L. Frio shale mineralogy and the stoichiometry of the smectiteto-illite reaction - the most important reaction in clastic sedimentary diagenesis. Clays Clay Min. 1997. 45: 618-631

Moraes M A S and De Ros L F. Depositional, infiltrated and authigenic clays in fluvial sandstones of the Jurassic Sergi Formation,
Reconcavo Basin, Northeast Brazil. In: Origin, Diagenesis and Petrophysics of Clay Minerals in Sandstones, Society of Economic Paleontologists and Mineralogists Special Publication. 1992. 47: 197-208

Peng J, Liu J K, Wang Y, et al. Origin and controlling factors of chlorite coatings - an example from the reservoir in the T3x Group of the Baojie area, Sichuan Basin, China. Pet. Sci. 2009. 6: 376-382 (in Chinese)

Pittman E D, R E Larese and M T Heald. Clay coats: Occurrence and relevance to preservation of porosity in sandstones, in $\mathrm{D}$. W. Houseknecht and E. D.Pittman, eds., Origin, diagenesis and petrophysics of clay minerals in sandstones: SEPM Special Publication. 1992. 47: 241-264

Sun Z L, Huang S J, Zhang Y X, et al. Origin and Diagenesis of Authigenic Chlorite within the Sandstone Reservoirs of the Xujiahe Formation, Sichuan Basin, China. Acta Sedimentologica Sinica. 2008. 26(3): 459-467 (in Chinese)

Thomson A. Preservation of porosity in the deep Woodbine/Tuscaloosa trend, Louisiana: Gulf Coast Association of Geological Societies Transactions. 1979. 30: 396-403

Tian J F, Chen Z L, Fan Y F, et al. The Occurrence, Growth Mechanism and Distribution of Authigenic Chlorite in Sandstone. Bulletin of Mineralogy, Petrology and Geochemistry. 2008. 27(2): 200-205 (in Chinese)

Wang F R, He S, He Z L, et al. Effect of grain-coating chlorite on reservoir properties of the Yongjin area in the centre of Junggar Basin. Journal of Daqing Petroleum Institute. 2007. 31(2): 24-27 (in Chinese)

Wang Q, Shi J A, Xue L H, et al. Characteristics of Fluid-Rock Interaction in Clastic Reservoir Controlled by Evolution of Diagenetic Environment--Taking the southwest depression of the Tarim basin as an example. Acta Sedimentologica Sinica. 1999. 17(4): 584-590 (in Chinese)

Xie L H, Lin C S, Dong W. Restoration of palaeogeomorphology and favorable reservoir bodies distribution of the Panyu Low Uplift. Petroleum Geology and Oilfield Development in Daqing, 2009. 28(3): 10-14 (in Chinese)

Yu X H , Jiang H, Shi H S, A Study of the Depositional Characteristic and Diagenetic Evolvement in the Panyu Gas Field of the Peal River Mouth Basin. Acta Sedimentologica Sinica, 2007. 25(6): 876-884 (in Chinese)

Zhang C M, Li S T, Yang J M, Yang S M and Wang J R, 2004. Petroleum migration and mixing in the Pearl River Mouth Basin, South China Sea. Marine and Petroleum Geology. 21: 215-224

Zhang Z T, Shi H S, Qin C G, et al. A Study of fault sealability of the Panyu low massif and the north slope of Baiyun Sag. Fault-block Oil \& Gas Field. 2010. 37(3): 297-303 (in Chinese)

Zhu R K, Zou C N, Zhang N, et al. Diagenetic fluids evolution and genetic mechanism of tight sandstone gas reservoirs in the Upper Triassic Xujiahe Formation in Sichuan Basin, China, Sci China Ser D-Earth Sci. 2008. 50(1): 1340-1353

(Edited by Yang Lei) 